\title{
Genetic Divergence Studies in Ajwain (Trachyspermum ammi L.) Genotypes
}

\author{
Narendra Pratap Singh*, V.P. Pandey, Gulab Chand Yadav, Gaurav Singh, \\ Nidhi Tyagi, Prashasti Pandey and Praveen Kumar Maurya
}

Department of Vegetable Science, Narendra Deva University of Agriculture and Technology, Kumarganj, Faizabad-224229, Uttar Pradesh, India

*Corresponding author

\begin{tabular}{|c|c|}
\hline & A B S T R A C T \\
\hline & \multirow{6}{*}{$\begin{array}{l}\text { Knowledge of genetic divergence provides us a sound scientific basis for the selection of } \\
\text { genotypes to be used in hybridization programme for further improvement. A field } \\
\text { experiment was conducted during Rabi season, 2014-15 at Main Experiment Station } \\
\text { (Vegetable Research Farm), N. D. U. A. \& T., Kumarganj, Faizabad (U.P.) India, to } \\
\text { estimate genetic divergence among the } 30 \text { genotypes of ajwain for ten characters by using } \\
\text { Mahalanobis } \mathrm{D}^{2} \text { analyses. The genotypes under study grouped into six clusters. Among the } \\
\text { six clusters, cluster IV was the largest, comprising of } 7 \text { genotypes. The inter-cluster } \\
\text { distance was larger than the intra-cluster distance suggesting wider genetic diversity } \\
\text { among the genotypes of different groups. The maximum and minimum intra- cluster } \\
\text { distances were found in cluster IV ( } 83.61 \text { ) and cluster VI (29.15), respectively. The inter- } \\
\text { cluster } \mathrm{D}^{2} \text { values was maximum between the cluster III and IV (198.03) indicating wide } \\
\text { range of genetic diversity between these two clusters. The maximum cluster mean was } \\
\text { observed in cluster VI for seed yield/plant ( } 36.44) \text { along with number of branches/plant } \\
\text { (10.45). The characters like test weight ( } 32.41 \% \text { ), number of umbellets per umbel } \\
\text { (20.46\%) and days to maturity (17.01\%) contributed maximum to genetic divergence and } \\
\text { hence played a major role in improvement of ajwain. }\end{array}$} \\
\hline Keywords & \\
\hline $\begin{array}{l}\text { Trachysp } \\
\text { L., Genet } \\
\text { Cluster at }\end{array}$ & \\
\hline Article Info & \\
\hline $\begin{array}{l}\text { Accepte } \\
\text { 07 Sept } \\
\text { Availab } \\
10 \text { Nove }\end{array}$ & \\
\hline & \\
\hline
\end{tabular}

\section{Introduction}

Trachyspermum ammi L. Syn. Carum copticum, commonly known as Bishop's weed or ajowan or ajwain, cultivated as herbaceous herb belonging to the family Apiaceae and vastly grows in Egypt, Iran, Pakistan, Afghanistan, and India as well as European region (Shojaaddini et al., 2008). In India, it's cultivated in Madhya Pradesh, Uttar Pradesh, Gujarat, Rajasthan, Maharashtra, Bihar and West Bengal (Anonymous, 19992011). The total area and production of ajwain in India are about 0.024 Mha and $0.014 \mathrm{Mt}$, respectively with 0.58 tonnes per hectare productivity (Anonymous, 2016-17). Usually greyish brown seeds or fruits of ajwain are considered for medical and nutritional purposes (Chauhan et al., 2012). It has been used as culinary spice worldwide and resembles thyme. Fruits were widely administered as a food flavouring agent and as a digestive stimulant (Jeet et al., 2012). Genetic divergence is an essential prerequisite factor in any crop improvement programme to identify potential parents for hybridization and to achieve high yielding variety (Marker and Krupakar, 2009). The knowledge of 
morphological variability, its nature and magnitude are essential for selecting genetically divergent parents to obtain the desirable recombinant in the segregating generations upon crossing. Hence, the present study was therefore undertaken to provide information on nature and magnitude of genetic diversity among promising 30 ajwain genotypes.

\section{Materials and Methods}

The experimental materials consisted of 30 diverse germplasm lines was laid in Randomized Block Design with three replications during Rabi season, 2014-15 at Main Experiment Station (Vegetable Research Farm), Narendra Deva University of Agriculture and Technology, Kumarganj, Faizabad, India $\left(26.47^{\circ}\right.$ North latitude and $82.12^{\circ}$ East longitudes at an altitude of $113 \mathrm{~m}$ above the mean sea level). The plot size was of $0.6 \mathrm{~m} \mathrm{x} 1.80 \mathrm{~m}$ with row to row spacing of $45 \mathrm{~cm}$ and plant to plant spacing of $20 \mathrm{~cm}$. All the recommended package of practices was followed to raise a healthy crop. The observations were recorded on five randomly selected plants from each genotype in each replication for the characters viz., plant height (cm), number of branches per plant, number of umbels per plant, number of umbellates per umbel, weight of grains per umbel $(\mathrm{g})$, test weight (g) and seed yield per plant $(\mathrm{g})$, while for germination (\%), days to $50 \%$ flowering and days to maturity, the data were recorded as whole plot basis. Genetic divergence was estimated using $\mathrm{D}^{2}$ statistics of Mahalanobis (1936), while method of cluster composition was done as per Tocher's method as described by Rao (1952).

\section{Results and Discussion}

The study of genetic divergence among the 30 genotypes of ajwain was carried out using Mahalanobis $\mathrm{D}^{2}$ statistics. The analysis of variance revealed that highly significant differences among the genotypes (Table 1) for all the traits under study depicting greater diversity in the existing material. Genetic diversity among the genotypes could be due to factors like heterogeneity, genetic architecture of the populations and developmental traits as described by Murty and Arunachalam (1966).

\section{Grouping of genotypes into various clusters}

Thirty genotypes were grouped into six different non over lapping clusters as per Tocher's method as described by Rao (1952). Cluster IV had highest number of genotypes (7) followed by cluster I and III had 6 genotype each whereas, cluster II and VI had 4 genotypes each while, cluster $\mathrm{V}$ had 3 genotypes (Table 2). Similar finding were also recorded in coriander (Bhandari and Gupta, 1993; Srivastava et al., 2000; Singh et al., 2012 and Meena et al., 2014).

The grouping pattern of genotypes was observed to be random, indicating that geographical diversity and genetic divergence were unrelated. Such observation has been reported by Rasul et al., (2004). The absence of relationship between genetic diversity and geographical distance indicates that forces other than geographical origin such as exchange of genetic stock, genetic drift, spontaneous mutation, natural and artificial selection are responsible for genetic diversity. Therefore, selection of genotypes for hybridization should be based on genetic divergence rather than geographic divergence (Mehta et al., 2004).

\section{Average intra- and inter cluster distances}

The estimates of intra- and inter cluster values represented by $\mathrm{D}^{2}$ values (Table 3 ). The intracluster distance ranged from 29.15 (Cluster VI) to 83.61 (cluster IV). 
Table.1 Analysis of variance (mean sum of squares) for 10 characters in azwain

\begin{tabular}{|c|c|c|c|c|}
\hline \multirow{3}{*}{$\begin{array}{l}\text { Sl. } \\
\text { No. }\end{array}$} & \multirow{2}{*}{ Characters } & \multicolumn{3}{|c|}{ Source of variation } \\
\hline & & Replication & Treatments & Error \\
\hline & d. f. & 2 & 29 & 58 \\
\hline 1. & Germination $(\%)$ & 1.741 & $52.004^{* *}$ & 4.762 \\
\hline 2. & Days to $50 \%$ flowering & 7.811 & $52.958^{* *}$ & 20.339 \\
\hline 3. & Number of branches per plant & 0.000 & $4.274^{* *}$ & 0.220 \\
\hline 4. & Number of umbels per plant & 0.238 & $7.148^{* *}$ & 1.969 \\
\hline 5. & Number of umbellets per umbel & 0.976 & $26.592^{* *}$ & 0.757 \\
\hline 6. & Weight of grains per umbel (g) & 0.002 & $0.071^{* *}$ & 0.002 \\
\hline 7. & Plant height $(\mathrm{cm})$ & 0.170 & $17.854^{* *}$ & 5.245 \\
\hline 8. & Days to maturity & 0.652 & $304.851^{* *}$ & 12.851 \\
\hline 9. & Test weight (g) & 0.022 & $0.600^{* *}$ & 0.014 \\
\hline 10. & Seed yield per plant $(\mathrm{g})$ & 2.534 & $24.615^{* *}$ & 6.062 \\
\hline
\end{tabular}

*, ** Significant at $\mathrm{P}<0.05$ and $\mathrm{P}<0.01$, respectively

Table.2 Clustering pattern of 30 genotypes of ajwain (Tocher's method)

\begin{tabular}{|c|c|l|}
\hline Clusters & No. of genotypes & Genotypes \\
\hline I & 6 & NDAZ-1, NDAZ-2, NDAZ-21, NDAZ-3, NDAZ-9, NDAZ-29 \\
\hline II & 4 & NDAZ-4, NDAZ-18, NDAZ-8, NDAZ-23 \\
\hline III & 6 & NDAZ-16, NDAZ-25, NDAZ-17, NDAZ-24, NDAZ-28, NDAZ-27 \\
\hline IV & 7 & NDAZ-6, NDAZ-11, NDAZ-13, NDAZ-19, NDAZ-12, NDAZ-14, NDAZ-15 \\
\hline V & 3 & NDAZ-7, GA-1, NDAZ-10 \\
\hline VI & 4 & NDAZ-22, NDAZ-26, NDAZ- 5, NDAZ-20 \\
\hline
\end{tabular}


Table.3 Average intra (bold) and inter-cluster $D^{2}$ values for six clusters in 30 genotypes of ajwain (Tocher's method)

\begin{tabular}{|c|c|c|c|c|c|c|}
\hline Clusters & $\mathrm{I}$ & II & III & IV & $\mathrm{V}$ & VI \\
\hline I & 72.10 & 148.27 & 116.63 & 142.22 & 192.80 & 122.16 \\
\hline II & & 47.26 & 116.61 & 181.14 & 177.03 & 108.95 \\
\hline III & & & 75.50 & 198.03 & 193.65 & 129.80 \\
\hline IV & & & & 83.61 & 154.18 & 117.45 \\
\hline $\mathrm{V}$ & & & & & 49.88 & 83.50 \\
\hline VI & & & & & & 29.15 \\
\hline
\end{tabular}

*Bold diagonal values indicate intra cluster distance, rest of the values show the inter cluster distances.

Table.4 Mean values of clusters for 10 characters in 30 genotypes of ajwain (Tocher's method)

\begin{tabular}{|c|c|c|c|c|c|c|c|c|c|c|}
\hline Characters & Germination $(\%)$ & $\begin{array}{l}\text { Days to } 50 \% \\
\text { flowering }\end{array}$ & $\begin{array}{c}\text { Number of } \\
\text { branches } \\
\text { per plant }\end{array}$ & $\begin{array}{c}\text { Number of } \\
\text { umbels } \\
\text { per plant }\end{array}$ & $\begin{array}{c}\text { Number of } \\
\text { umbellets per } \\
\text { umbel }\end{array}$ & $\begin{array}{l}\text { Weight of } \\
\text { grains per } \\
\text { umbel }(\mathrm{g})\end{array}$ & $\begin{array}{l}\text { Plant } \\
\text { height } \\
\text { (cm) }\end{array}$ & $\begin{array}{l}\text { Days to } \\
\text { maturity }\end{array}$ & $\begin{array}{c}\text { Test } \\
\text { weight } \\
(\mathrm{g})\end{array}$ & $\begin{array}{c}\text { Seed yield } \\
\text { per plant } \\
(\mathrm{g})\end{array}$ \\
\hline I & 90.48 & 97.16 & 9.77 & 34.13 & 17.53 & 1.35 & 106.63 & 169.20 & 2.341 & 31.61 \\
\hline III & 85.43 & 94.88 & 8.85 & 32.63 & 16.80 & 1.17 & 106.51 & 187.04 & 2.766 & 34.36 \\
\hline IV & 90.77 & 98.71 & 8.57 & 33.96 & 19.66 & 1.14 & 107.71 & 170.56 & 1.806 & 33.34 \\
\hline $\mathrm{V}$ & 88.97 & 92.55 & 8.51 & 33.64 & 25.48 & 1.20 & 108.22 & 183.86 & 2.336 & 32.07 \\
\hline VI & 90.85 & 91.00 & 10.45 & 34.50 & 21.01 & 1.18 & 107.56 & 185.76 & 2.206 & 36.44 \\
\hline
\end{tabular}

Table.5 Percent contribution of different traits towards divergence of 30 germplasm lines of ajwain

\begin{tabular}{|c|l|c|}
\hline Sl. No. & Characters & Per cent contribution \\
\hline 1. & Germination $(\%)$ & 3.91 \\
\hline 2. & Days to 50\% flowering & 0.00 \\
\hline 3. & Number of branches per plant & 0.97 \\
\hline 4. & Number of umbels per plant & 20.46 \\
\hline 5. & Number of umbellets per umbel & 12.87 \\
\hline 6. & Weight of grains per umbel $(\mathrm{g})$ & 0.69 \\
\hline 7. & Plant height $(\mathrm{cm})$ & 17.01 \\
\hline 8. & Days to maturity & 32.41 \\
\hline 9. & Test weight $(\mathrm{g})$ & 3.22 \\
\hline 10. & Seed yield per plant $(\mathrm{g})$ & \\
\hline
\end{tabular}


Among the six clusters, the intra- cluster distance was maximum in cluster IV (83.61) followed by cluster III (75.50) and cluster I (72.10), while the minimum intra- cluster distance was observed in cluster VI (29.15) followed by cluster II (47.26). Similar kind of results in coriander was also reported by several researchers (Srivastava et al., 2000; Palanikumar et al., 2012; Dyulgerov and Dyulgerova, 2013 and Meena et al., 2014). The intra -cluster values are lesser than the inter- cluster values which indicates the homogenous and heterogenous nature of the genotypes within and between the clusters, respectively.

The maximum inter-cluster distance was observed between cluster III and clusters IV (198.03) followed by cluster III and V (193.65), cluster I and clusters V (192.80), whereas the minimum inter-cluster distance was observed between Cluster $\mathrm{V}$ and VI (83.50) indicating close relationship among the genotypes belonging to these clusters. These results are in agreement with the findings of Palanikumar et al., (2012) Dyulgerov and Dyulgerova (2013) and Meena et al., (2014) in coriander. Hence, inter mating between the genotypes included in these clusters could be expected to give transgressive segregates in the advanced generation as suggested by Kalloo et al., (1980).

\section{Mean value of the clusters}

The diversity among the genotypes was also substantiated by the considerable amount of variation among cluster means for different characters which might be the reason for large inter cluster distances. The cluster means of 30 genotypes showed that the mean values of the clusters varied in magnitude for all the 10 characters (Table 4). Cluster VI (36.44) was the highest seed yielder followed by cluster III (34.36). Regarding test weight, cluster II
(2.82) showed highest performance followed by cluster III (2.76). Highest number of umbels per plant was produced in the genotypes cluster II (34.51) followed by the genotypes under cluster VI (34.50). Number of umbellets per umbel was highest in cluster V (25.48) whereas, weight of grains per umbel was highest in cluster I (1.35). Cluster II (91.83) was found maximum germination percentage while, cluster VI (91.00) was found best as minimum days for days to $50 \%$ flowering is desirable.

Thus, the maximum cluster mean was observed in cluster VI for seed yield/plant along with number of branches/plant, while Cluster V for number of umbellets per umbel and plant height; cluster II for number of umbels per plant and test weight. These clusters could be regarded as useful sources of gene for important yield component traits. However, Cluster VI had lowest number of days to appearance of $50 \%$ flowering, while Cluster I had earliest appearance of days to maturity which could be helpful for breeding an early plant type. Hence, it can be suggested from the present study that a high yielding early flowering type with number of branches of branches per plant could be bred by utilizing the genotypes from cluster VI as parents in the future breeding programme. Similar observations were also reported by Bhandari and Gupta (1993), Srivastava et al., (2000), Singh et al., (2012), Dyulgerov and Dyulgerova (2013) and Meena et al., (2014) in coriander.

\section{Character contribution towards divergence}

An assessment of relative maximum contribution of 10 characters towards total genetic divergence (Table 5) was recorded in test weight $(32.41 \%)$ followed by number of umbellets per umbel (20.46\%), days to maturity $(17.01 \%)$, weight of grains per umbel $(12.87 \%)$ and number of branches per 
plant $(8.97 \%)$,while germination percentage (3.91\%), seed yield per plant $(3.22 \%)$, plant height $(0.69 \%)$, and number of umbels per plant $(0.46 \%)$ have the least contribution. Our results are in accordance with the findings of Patel et al., (2000), Palanikumar et al., (2012) and Meena et al., (2014) in coriander.

\section{References}

Anonymous 1999-2011. Ayurvedic Pharmacopoeia of India. Government of India, Ministry of Health and Family Welfare, Department of Ayush. 1(1): 170-171.

Anonymous 2016-17. Horticulture Data Base, $2^{\text {nd }}$ Est., National Horticulture Board, Gurugram, Ministry of Agriculture and Farmer's Welfare, India.

Bhandari, M.M., and Gupta, A. 1993. Divergence analysis in coriander. Indian Journal of Genetics and Plant Breeding. 53(1): 71-75.

Chauhan, B., Kumar, G., and Ali, M. 2012. A Review on phytochemical constituents and activities of Trachyspermum ammi (L.) sprague fruits. International Journal of Pharmaceutical Sciences and Research. 2(4):329-340.

Dyulgerov, N., and Dyulgerova, B. 2013. Genetic divergence among accession of coriander. Journal of Agricultural Science and Technology. 5(1): 13-15.

Jeet, K., Devi, N., Thakur, N., Tomar, S., Shalta, L., and Thakur, R. 2012. Trachyspermum ammi L. A comprehensive review. International Research Journal of Pharmacy. 3: 133138.

Kalloo, G., Singh, V.P., Dudi, B.S., and Partap, P.S. 1980. Analysis of variation and genetic divergence in garden peas (Pisum sativum L.). Haryana Agricultural University Journal of Research, 10: 540-46.

Mahalanobis, P.C. 1936. On the generalized distances in statistics. Proceedings of
National Academy of Sciences in India. 2: 49-55.

Marker, S., and Krupakar, A. 2009. Genetic divergence in exotic maize germplasm (Zea mays L.). Journal of Agricultural and Biological Science. 4: 44-47.

Meena, K., Sharda R.S., Singh, R.K., Chaudhary, B., and Panwar, A. 2014. Genetic diversity analysis in coriander. Indian Journal of Agricultural Sciences. 84(12): 1508-1512.

Mehta, D.R., Golani,I.J, Pandya, H.M., Patel, R.K., and Naliyadhara, M.V. (2004). Genetic diversity in brinjal (Solanum melongena L.). Vegetable Science. 31: 142-145.

Murty, B.R., and Arunachalam, V. 1966. The nature of genetic diversity in relation to plant breeding system in crop plants. Indian Journal of Genetics and Plant Breeding. 26: 188-198.

Palanikumar, M., Rajamani, K., and Muthiah, A.R. 2012. Path coefficient analysis in coriander (Coriandrum sativum L.) genotypes for fresh biomass yield under different seasons. Crop Research. (Hisar). 44 (1/2): 222-226.

Patel, K.C., Tiwari, A.S., and Kushwaha, H.S. 2000. Genetic divergence in coriander. Agricultural Science Digest. 20(1): 1316.

Rao, C.R. 1952. Advanced statistical methods in biometrical research. Jhon Wiley and Sons Inc. NewYork, pp. 236-272.

Rasul, M.G., Hiramatsu, M., and Okubo, H. (2004). Morphological and physiological variation in kakrol (Momordica dioica Roxb.). Journal of the Faculty of Agriculture, Kyushu University. 49(1): 1-11.

Shojaaddini, M., Moharramipour, S. and Sahaf, B. 2008. Fumigant toxicity of essential oil from Carum copticum against Indian meal moth, Plodia interpunctella. Journal of Plant Protection Research. 48(4): 411-419. 
Singh, S.K., Kakani, R.K., Meena, R.S., Pancholy, A., and Pathak, R. 2012. Genetic diversity among Indian varieties of Foeniculum vulgare and Cuminxjm cyminum based on nuclear ribosomal DNA and RAPD analyses. International Journal of Agriculture and Statistical Science. 8(2): 493-502.
Srivastava, S.B.L., Kamaluddin, Tripathi, S.M., and Srivastava, J.P. 2000. Genetic divergence in coriander (Coriandrum sativum $\mathrm{L}$.). Spices and aromatic plants: challenges and opportunities in the new century. Centennial conference on spices and aromatic plants, Calicut, Kerala, India, pp. 68-70.

\section{How to cite this article:}

Narendra Pratap Singh, V.P. Pandey, Gulab Chand Yadav, Gaurav Singh, Nidhi Tyagi, Prashasti Pandey and Praveen Kumar Maurya. 2017. Genetic Divergence Studies in Ajwain (Trachyspermum ammi L.) Genotypes. Int.J.Curr.Microbiol.App.Sci. 6(11): 563-569. doi: https://doi.org/10.20546/ijcmas.2017.611.068 